\title{
Analysis Relationship of the Pulmonary TB Prisoners with the Prevention Measures in Jail In Province of Sumatera Utara
}

\author{
Lina Tarigan ${ }^{1}$, R. Kintoko Rochadi ${ }^{2}$ \\ ${ }^{1,2}$ Senior Lecturer of Faculty of Public Health, Universitas Sumatera Utara, Medan Indonesia
}

\begin{abstract}
According to the WHO (2013), the pulmonary TB as the second order of death and has infected 9.4 million people and killed 1.7 million people in the world each year. Indonesia ranks second highest number of TB cases in the world with an incidence of 391 per 100,000 inhabitants. The prevalence rate of pulmonary TB in prison is estimated to be 3 times higher than the general population. The research aims to analyze the characteristics relationships of the prisoners community with pulmonary TB with precautions and transmission in jails in Sumatera Utara province. The research was conducted in jails in the city of Medan and Lubuk Pakam using cross sectional design. The population is all prisoners with pulmonary TB undergoing treatment. The research sample is all the pulmonary TB sufferers recorded at the both jail clinics. The results showed there was a relationship between the characteristics of prisoners with precautions in ethics of cough $(p=0.01)$, precautions in habit of throwing sputum $(p=0.046)$, preventive measures in habit of using masks $(p=0.001)$ in the jail of Sumatera Utara Province
\end{abstract}

Keywords: Pulmonary TB, jail, preventive measure.

\section{Introduction}

The incidence of pulmonary TB is still high in society, so that Indonesia still ranks the 2 highest number of sufferers in the world. There are reportedly 1 million cases of pulmonary TB or 399 cases per 100,000 population $^{1}$. Based on a survey of the prevalence of TB 2013 and Global Report 2015 estimated pulmonary TB incident in Sumatra Utara Province in 2017 at 73,488 with incidence rate $515 / 100,000$ and total death of 5,847 with Case Specific Date Rate (CSDR) 41/100,000 inhabitants. Case Detection Rate (CDR) Sumatra Utara Province in 2017 is $37.17 \%$, still $50 \%$ under target achievment $^{2}$.

The prevalence rate of pulmonary TB in prison is estimated to be 3 times higher than the population of common $^{3}$. Agung Setiadi and Reviono (2016) stated that TB's disease occupies the 4th most common illness and is one of the main causes of pain and death in jail all over Indonesia ${ }^{4}$. The prisoners situation where the exceeds capacity make worse the vulnerability and increase the transmission of pulmonary TB. The research conducted by Sadi at the jail of Narcotics prisoners in Jakarta showed that the implementation of the program has not been effective because it has not been achieved getting to zero case TB.

Research conducted by Rosalina Thuffi and Milla Herdayati (2013) on the risk of TB incidence with Case Control Study at the jail of narcotics in Jakarta in 2013 showed that there was influence of marital status in unmarried groups, education level less than high school, injected drugs use, nutritional status, long prisoners, history of ever held, TB history in family, and the existence of TB in one room with the risk of occurrence of $\mathrm{TB}^{5}$.

Based on the research of Putri, EA et al (2018) there was an influence of cough behavior on the incidence of pulmonary TB in Semarang Jail $(p=0.022$; OR $=$ 3.93; 95\% CI: $1.29-8,44)^{6}$. Research Chiang CY et al (2002) that from 51,496 prisoners were diagnosed 107 pulmonary TB (258.7 per 100,000 population) where $88(82.2 \%)$ is a new case. This shows the high risk of transmission of pulmonary TB among prisoners in jail ${ }^{7}$. Larouzé B et, al (2015) found that there was an influence of age ( $\geq 30$ years) on the occurrence of pulmonary TB in the Abidjan prison, Ivory Coast of West Africa $(\mathrm{OR}=$ 
3.8; 95\% CI: $1.1-13.3$ ) and a case of pulmonary TB in prison 10 to 44 times higher than common population ${ }^{8}$.

The Department of Law and Human Rights report of Sumatera Utara Province said that during the period 2009-2011, the new pulmonary TB case of prison occupants tends to increase every year, the increase was an average of $7.2 \%$. Research of Milla and Rosalina Thuffi's stated that the management of the prison needs to cope with the transmission of pulmonary TB in accordance with the policy and the National Action Plan against the Public Private Mix ${ }^{5}$. Some elements may influence the occurrence transmission of pulmonary TB among communities and to certain people including the management, patient care and nutritional food consumption $^{9-13}$. Based on the background above, it is necessary to do research on the relationship of the pulmonary TB prisoners with the prevention measures in jail in Province of Sumatera Utara

\section{Method}

This research design is cross sectional study. The population is all prisoners with pulmonary $\mathrm{TB}$ who are undergoing treatment in jail in Sumatra Utara Province. Samples amounted to 59 prisoners. The Data is done by conducting interviews using questionnaires. Questionnaires were disseminated to respondents after approval from the Faculty of Ethics Committee of the Universitas Sumatera Utara and approval from respondents.

\section{Results}

Precautions In The Ethics Of Cough

Table 1. The Relationship of characteristics of prisoner with the ethics of cough pulmonary TB in the Jail of Sumatra Utara Province

\begin{tabular}{|c|c|c|c|c|c|c|c|}
\hline \multirow{3}{*}{ Characteristics of Prisoners } & \multicolumn{4}{|c|}{ Ethics Cough } & \multirow{2}{*}{\multicolumn{2}{|c|}{ Total }} & \multirow{3}{*}{$\mathbf{p}$} \\
\hline & \multicolumn{2}{|c|}{ Bad } & \multicolumn{2}{|c|}{ Good } & & & \\
\hline & $\mathbf{F}$ & $\%$ & f & $\%$ & f & $\%$ & \\
\hline \multicolumn{8}{|l|}{ Age } \\
\hline$\leq 40 \mathrm{yrs}$ & 9 & 30 & 21 & 70 & 30 & 100 & \multirow{2}{*}{0,831} \\
\hline$>40 \mathrm{yrs}$ & 7 & 24,1 & 22 & 75,9 & 29 & 100 & \\
\hline \multicolumn{8}{|l|}{ Last Education } \\
\hline Low & 7 & 24,1 & 22 & 75,9 & 29 & 100 & \multirow{2}{*}{0,831} \\
\hline High & 9 & 30 & 21 & 70 & 30 & 100 & \\
\hline \multicolumn{8}{|l|}{ Marital Status } \\
\hline Not Marriage & 8 & 32 & 17 & 68 & 25 & 100 & \multirow{2}{*}{0,67} \\
\hline Marriage & 8 & 23,5 & 26 & 76,5 & 34 & 100 & \\
\hline \multicolumn{8}{|l|}{ Length in jail } \\
\hline$\geq 24$ month & 13 & 50 & 13 & 50 & 26 & 100 & \multirow{2}{*}{0,01} \\
\hline$<24$ month & 3 & 9,1 & 30 & 90,9 & 33 & 100 & \\
\hline
\end{tabular}


Based on table 1 It showed that the proportion of patients with a pulmonary TB aged $\leq 40$ years have poor cough ethics by not covering the mouth when coughs of 9 people (30\%) higher than that of the pulmonary prisoner aged $>40$ years, 7 people (24.1\%). Based on the results of the chi-square test obtained the $p$-value $>0.05$ which means there is no age relationship with the ethics of cough. The proportion of prisoner with a pulmonary TB who has a low education with a poor cough ethics of 7 people $(24.1 \%)$ lower than with prisoners with pulmonary TB who has a higher education of 9 people $(30 \%)$, the test results of the chi-square obtained the $p$-value $>0.05$ which means there is no last education relationship with the ethics of cough.
Prisoners with pulmonary TB who did not married with poor ethics cough is 8 people (32\%) higher than prisoners with married prisoners pulmonary $\mathrm{TB}$, which is 8 people $(23.5 \%)$. Based on the results of the chisquare test obtained the $p$-value $>0.05$ which means there is no relationship of marital status with the ethics of cough. The proportion of prisoners with pulmonary TB who stay in jail $\geq 24$ month with a poor cough ethics is 13 people $(50 \%)$ higher than that of prisoners who stay in jail $<24$ month for 3 people $(9.1 \%)$ Chi-Square test results obtained the $p$-value $<0.05$ which means there is a relationship of length stay in jail with the ethics of cough.

\section{Throwing Sputum Prevention}

Table 2 The Relationship characteristic of Prisoner With The Habit of Throwing Sputum in the Jail of Sumatera Utara Province

\begin{tabular}{|c|c|c|c|c|c|c|c|}
\hline \multirow{3}{*}{ Characteristic Of prisoners } & \multicolumn{3}{|c|}{ Throwing Sputum } & \multirow{2}{*}{\multicolumn{3}{|c|}{ Total }} & \multirow{3}{*}{$\mathrm{p}$} \\
\hline & \multicolumn{2}{|c|}{$\mathrm{Bad}$} & \multirow{2}{*}{$\frac{\text { Good }}{\mathrm{f}}$} & & & & \\
\hline & $\mathrm{f}$ & $\%$ & & $\%$ & $\mathrm{~F}$ & $\%$ & \\
\hline \multicolumn{8}{|l|}{ Age } \\
\hline$\leq 40 \mathrm{yrs}$ & 5 & 16,7 & 25 & 83,3 & 30 & 100 & 0,950 \\
\hline$>40 \mathrm{yrs}$ & 6 & 20,7 & 23 & 79,3 & 29 & 100 & \\
\hline \multicolumn{8}{|l|}{ Education } \\
\hline Low & 6 & 20,7 & 23 & 79,3 & 29 & 100 & 0,950 \\
\hline High & 5 & 16,7 & 25 & 83,3 & 30 & 100 & \\
\hline \multicolumn{8}{|l|}{ Marital Status } \\
\hline Marriage & 5 & 14,7 & 29 & 85,3 & 34 & 100 & 0,502 \\
\hline No Marriage & 6 & 24,0 & 19 & 76,0 & 25 & 100 & \\
\hline \multicolumn{8}{|l|}{ Length in jail } \\
\hline$\geq 24$ month & 8 & 30,8 & 18 & 69,2 & 26 & 100 & 0,046 \\
\hline$<24$ month & 3 & 9,1 & 30 & 90,9 & 33 & 100 & \\
\hline
\end{tabular}

Based on the table known that the proportion of patients with pulmonary $\mathrm{TB}$ at age $\leq 40$ years that has a habit of poor throwing sputum is 5 people $(16.7 \%)$ lower than with prisoners with pulmonary TB at the age of $>40$ years is 6 people (20.7\%). Based on the test Chi Square obtained the $p$-value $>0.05$ which means there is no 
relationship between the age with the habit of throwing sputum. Proportion of prisoners with pulmonary TB who have a low education with a habit of poor throwing sputum $(20.7 \%)$ higher than that of patients with a pulmonary TB who has a higher education of 5 people (16.7\%), the test results of the Chi Square are obtained $p>0.05$ which means there is no relationship between education and the habit of throwing sputum.

Proportion of prisoners of pulmonary TB who has married the habit of bad throwing sputum is 5 people (14.7\%) lower than the proportion of prisoners of pulmonary TB who do not married is 6 people $(24 \%)$, the results of the Chi square test obtained the $p$-value $>0.05$ which means there is no relationship between marital status and the habit of throwing sputum.

Prisoners with a pulmonary TB who has $\geq 24$ month in jail have a poor habit in throwing sputum is 8 people $(30.8 \%)$ higher than the proportion of prisoners pulmonary TB who had been $<24$ month is 3 people $(9.1 \%)$, the test results of the Chi square was obtained $p$-value $<0.05$ which means there is a relationship between the length in jail with the habit of throwing sputum.

\section{Precautions In Smoking Habits}

Table 3 The Relationship of Characteristics of Prisoners with Smoking Habit in the Jail of Sumatra Utara Province

\begin{tabular}{|c|c|c|c|c|c|c|c|}
\hline \multirow{3}{*}{ Characteristic of Prisoners } & \multicolumn{4}{|c|}{ Smoking Habit } & \multirow{2}{*}{\multicolumn{2}{|c|}{ Total }} & \multirow{3}{*}{$\mathbf{P}$} \\
\hline & \multicolumn{2}{|c|}{ No } & \multicolumn{2}{|c|}{ Yes } & & & \\
\hline & f & $\%$ & f & $\%$ & $\mathbf{F}$ & $\%$ & \\
\hline \multicolumn{8}{|l|}{ Age } \\
\hline$\leq 40 \mathrm{yrs}$ & 16 & 53,3 & 14 & 46,7 & 30 & 100 & 0,355 \\
\hline$>40 \mathrm{yrs}$ & 11 & 37,9 & 18 & 62,1 & 29 & 100 & \\
\hline \multicolumn{8}{|l|}{ Education } \\
\hline Low & 14 & 48,3 & 15 & 51,7 & 29 & 100 & 0,905 \\
\hline High & 13 & 43,3 & 17 & 56,7 & 30 & 100 & \\
\hline \multicolumn{8}{|l|}{ Marital Status } \\
\hline Marriage & 15 & 44,1 & 19 & 55,9 & 34 & 100 & 0,975 \\
\hline Not Marriage & 12 & 48,0 & 13 & 52,0 & 25 & 100 & \\
\hline \multicolumn{8}{|l|}{ Length in jail } \\
\hline$\geq 24$ month & 9 & 34,6 & 17 & 65,4 & 26 & 100 & 0,207 \\
\hline$<24$ month & 18 & 54,5 & 15 & 45,5 & 33 & 100 & \\
\hline
\end{tabular}


According to table 3 the proportion of prisoners with pulmonary TB aged $\leq 40$ with smoking habit is 14 people $(46.7 \%)$ lower than the proportion of the prisoners of pulmonary TB aged $>40$ years is 18 people $(62.1 \%)$. Based on the results of the Chi square test obtained the $p$-value $>0,355$ which means there is no relationship between the age with the habit of smoking.

Prisoners with pulmonary TB who have a low education smoking habit is 15 people $(51.7 \%)$ lower than the proportion of pulmonary TB who has a higher education of 17 people $(56.7 \%)$. Based on the results of the Chi square test obtained the $p$-value $>0,905$ which means there is no relationship between education and smoking habit.

The proportion of unmarried prisoners with pulmonary TB with a smoking habit is 19 people $(55.9 \%)$ higher than the proportion of married prisoners of pulmonary TB is 13 people $(52 \%)$, the test results of Chi Square are obtained the $p$-value $>0,975$ which means there is no relationship between marital status and smoking habit.

Prisoners with pulmonary TB who has $\geq 24$ month in the jail with smoking habit is 17 people $(65.4 \%)$ higher than the proportion of prisoners with $<24$ month in the jail is 15 people (45.5\%). Based on the results of the Chi square test obtained the $p$-value $>0,207$ which means there is no relationship between the length of stay in jail with smoking habit.

\section{Precautions In Habit Using Masks}

Table 4 The Relationship of Characteristics of prisoners with the habit of using masks in the Jail of Sumatra Utara Province

\begin{tabular}{|c|c|c|c|c|c|c|c|}
\hline \multirow{3}{*}{ Characteristic of Prisoners } & \multicolumn{4}{|c|}{ Using Mask } & \multirow{2}{*}{\multicolumn{2}{|c|}{ Total }} & \multirow{3}{*}{$\mathbf{P}$} \\
\hline & \multicolumn{2}{|l|}{ No } & \multicolumn{2}{|c|}{ Yes } & & & \\
\hline & F & $\%$ & f & $\%$ & F & $\%$ & \\
\hline \multicolumn{8}{|l|}{ Age } \\
\hline$\leq 40 \mathrm{yrs}$ & 9 & 30 & 21 & 70 & 30 & 100 & \multirow{2}{*}{0,831} \\
\hline$>40 \mathrm{yrs}$ & 7 & 24,1 & 22 & 75,9 & 29 & 100 & \\
\hline \multicolumn{8}{|l|}{ Education } \\
\hline Low & 7 & 24,1 & 22 & 75,9 & 30 & 100 & \multirow{2}{*}{0,831} \\
\hline High & 9 & 30 & 21 & 70 & 29 & 100 & \\
\hline \multicolumn{8}{|l|}{ Marital Status } \\
\hline Marriage & 8 & 23,5 & 26 & 76,5 & 34 & 100 & \multirow{2}{*}{0,669} \\
\hline No Marriage & 8 & 32 & 17 & 68 & 25 & 100 & \\
\hline \multicolumn{8}{|l|}{ Length in jail } \\
\hline$\geq 24$ month & 13 & 50 & 13 & 50 & 26 & 100 & \multirow{2}{*}{0,001} \\
\hline$<24$ month & 3 & 9,1 & 30 & 90,9 & 33 & 100 & \\
\hline
\end{tabular}


Based on table 4 proportion of patients with pulmonary TB at age $\leq 40$ years who did not use a mask is 9 people $(30.0 \%)$ higher than the prison aged $>40$ years is 7 people $(24.1 \%)$. Based on the results of the chi-square test obtained the $p$-value $>0.05$ which means there is no relationship between age with the habit of using masks.

Prisoners with pulmonary TB in low education who did not use a mask is 7 people $(24.1 \%)$ lower than prisoners with pulmonary TB who has a higher education is 9 people $(30.0 \%)$. The test results of the chi-square obtained the $p$-value $>0.05$ which means there is no relationship between education with the habit of using masks.

The proportion of unmarried prisoners with pulmonary TB with not using a mask is 8 people $(23.5 \%)$ higher than the proportion of married prisoners of pulmonary TB is 8 people (32\%), the test results of Chi Square are obtained the $p$-value $>0,975$ which means there is no relationship between marital status and using a mask habit. Prisoners with pulmonary TB who has $\geq$ 24 month in jail have using mask is 13 people $(50 \%)$ higher than the proportion of prisoners pulmonary TB who had been $<24$ month is 30 people $(90,9 \%)$, the test results of the Chi square was obtained $p$-value $<0.05$ which means there is a relationship between the length in jail with the habit of using a mask.

\section{Conclusion}

There is a relationship between length stay in jail with the cough habit $(p=0.01)$, the habit of throwing sputum $(p=0.046)$, and the habit of wearing masks ( $p=$ 0.001 ) in the Jail Sumatra Utara Province.

There is no relationship between age, education, and marital status with the cough habit, the habit of throwing sputum, and the habit of wearing masks in the jail Sumatera Utara Province

Acknowledgment: Thank you to the TALENTA Research Institute, Universitas Sumatera Utara for providing the research funding with contract number: 4167 / UN5.1.R / PPM / 2019. April 1, 2019.

Ethical Clearance- Taken from University ethical committee

\section{Conflict of Interest - Nil}

\section{References}

1. WHO., 2017. Global TB Report. Diakses melalui http://www.who.int/tb/publications/global_report/ en/

2. Dinkes Provinsi Sumatera Utara, 2018.

3. Direktorat Jenderal Pemasyarakatan Kementerian Hukum dan HAM RI. (2012) Rencana Aksi Nasional Pengendalian Tuberkulosis di Rutan, Lapas dan Bapas Tahun 2012 - 2014. Jakarta.

4. Agung Setiadi, Reviono. Upaya Penanggulangan TB di Rumah Tahanan Negaral Lembaga Permasyarakatan Se Eks Karesidenan Surakarta. fromhttp://pulmonologi.fk.uns.ac.id/wp-content/ uploads/2016/10/Abstrak-Tk6.pdf.

5. Herdayati, Milla dan Rosalina Thuffi. Risiko Kejadian Tuberkulosis : Studi Case Control Pada Warga Binaan Pemasyarakatan di Lembaga Pemasyarakatan Narkotika Kelas II A Jakarta Tahun 2013. Respository. usu.ac.id.

6. Putri, E.A,. Martini., Saraswati. L.D., Faktor Risiko Tuberkulosis Paru Pada Warga Binaan Pemasyarakatan di Lembaga Pemasyarakatan Kelas I Semarang. E-Journal, Jurnal Kesehatan Masyarakat 2017. Vol. 6, No.1 from http:// ejournal3.undip.ac.id/index.php/jkm

7. Chiang CY., Hsu. CJ., Hsu. PK., Lin. Tp., Pulmonary TB in The Taiwanese Prison Population. 2002

8. Larouze, B,. Ventura, M., Sanchez, A.R., Diuana, V., TB in Brazilian prisons: responsibility of the State and double punishment for the inmates. 2015. Fromhttps://www.scielosp.org/article/ssm/ content/raw/?resource_ssm_path=/media/assets/ csp/v31n6/en

9. Anwar Mallongi, Stang, Syamsuar, Hasnawati Amqam, Aminuddin Syam, Syahrul Basri, Muh. Saleh. Target Cancer Risks Due To The Exposure From Silica Among The Communities Living Surround Cement Tonasa Industry Pangkep, Indonesia. Interciencia Journal. 2019 44(11)

10. Masriadi, Azis, R., Sumantri, E., Mallongi, A. Effectiveness of non pharmacologic therapy through surveillance approach to blood pressure degradation in primary hypertension patients, Indonesia. Indian Journal of Public Health Research and Development. vol: 9, issue : 4, 2018-04-01.

11. Sandu Siyoto, Anwar Mallongi, Muh Irfan Ilham, 
Syamsiar Russeng, Mustafa. Target Cancer Risks of Exposure to Carbon Monoxide and Plumbum among Attendants of Parking Lots in Panakkukang Mall and Panakkukang Square Makassar City. SRP. 2019; 10(1): 151155. doi:10.5530/srp.2019.1.28

12. Kayame, R., Mallongi, A. Relationships between smoking habits and the hypertension occurrence among the adults of communities. Indian Journal of Public Health Research and Development 2018. vol: 9. issue : 1, 2018-01-01

13. Anwar Mallongi, Ruslan La Ane and Agus Bintara Birawida. Ecological risks of contaminated lead and the potential health risks among school children in Makassar coastal area, Indonesia. J. Environ. Sci. Technol., 2017; 10: 283-289 